OPEN ACCESS

Edited by:

Larisa Ivascu,

Politehnica University of Timișoara,

Romania

Reviewed by:

G. M. Shafiqur Rahman,

Zhoukou Normal University, China

Xinmin Wang,

Northwest Normal University, China

*Correspondence:

Yichu Wang

wangyichu1993@163.com

Specialty section:

This article was submitted to

Environmental Economics and

Management,

a section of the journal

Frontiers in Environmental Science

Received: 30 October 2021

Accepted: 01 December 2021

Published: 19 January 2022

Citation:

lqbal $K$, Hassan ST, Wang $Y$, Shah MH, Syed M and Khurshaid $K$ (2022) To Achieve Carbon Neutrality Targets in Pakistan: New Insights of

Information and Communication

Technology and

Economic Globalization.

Front. Environ. Sci. 9:805360.

doi: 10.3389/fenvs.2021.805360

\section{To Achieve Carbon Neutrality Targets in Pakistan: New Insights of Information and Communication Technology and Economic Globalization}

\author{
Kashif Iqbal ${ }^{1}$, Syed Tauseef Hassan ${ }^{2}$, Yichu Wang ${ }^{3 *}$, Muhammad Haroon Shah $^{1}$, \\ Madeeha Syed ${ }^{4}$ and Khurshaid Khurshaid ${ }^{5}$
}

${ }^{1}$ College of International Students, Wuxi University, Wuxi, China, ${ }^{2}$ School of Business, Nanjing University of Information Science and Technology, Nanjing, China, ${ }^{3}$ School of Oriental and African Studies (SOAS), University of London, London, United Kingdom, ${ }^{4}$ Zulfikar Ali Bhutto Institute of Science and Technology, Karachi, Pakistan, ${ }^{5}$ Department of International Relation, University of Peshawar, Peshawar, Pakistan

In recent years, information and communication technology (ICT) is used in every sphere of life, from business to services, education to culture, infrastructure to transportation, and art to entertainment. The current study aims to assess the impact of ICT, economic growth, and globalization on $\mathrm{CO}_{2}$ emission in the context of Pakistan. For empirical estimation, the current study applied an innovative methodological approach called generalized linear model (GLM) and robust least square (ROBUSTLS) technique for the years 1990-2019. The key finding of this study shows that economic growth has a positive and significant effect on $\mathrm{CO}_{2}$ emission, which confirm that economic growth accelerates the rate of $\mathrm{CO}_{2}$ emission, while the study also reveals that ICT usage (more specifically ICT-internet and ICT-mobilesubscription) has a negative but significant effect on $\mathrm{CO}_{2}$ emission, which confirms that the usage of ICT (more specifically ICT-internet and ICT-mobile subscription) does not contribute positively to $\mathrm{CO}_{2}$ emission. Furthermore, the coefficient of globalization has a positive and significant effect on the $\mathrm{CO}_{2}$ emission, which confirms that globalization accelerates the $\mathrm{CO}_{2}$ emission in the country. Also, the results indicate that ICT usage (more specifically ICT-internet and ICT-mobile subscription) could boost economic growth and mitigate climate change. Based on the policy perspective, the government of Pakistan needs to strategically focus on the ICT sector and more specifically on technological innovations to promote sustainable economic growth in the country.

Keywords: carbon neutrality, information and communication technology, economic growth, economic globalization, Pakistan

\section{INTRODUCTION}

Today in the modern era of globalization, it is well-documented that information and communication technology (ICT) has wide-ranging impacts on key global systems and plays a key role in terms of both socioeconomic and cultural activities (Zhang and Liu, 2015; Salahuddin et al., 2016). Like other innovations, the development of ICT reshaped the modern world and revolutionized many sectors including the industrial sector through structural changes (Park et al., 
2018). ICT can have both positive and negative impacts on the environment. ICT is considered a leading growth enabler in countries that have realized its importance (Iqbal et al., 2019a). However, at the same time, ICT infrastructure has put significant pressure on the environment through resource consumption (Danish et al., 2019). It has been estimated that ICT generates $2 \%$ of global greenhouse gas (GHG) emissions via the use of digital PCs, internet servers, internet capability, fixed broadband, mobile telephones, local area network (LAN), and other related technologies (Bastida et al., 2019). On other hand, ICT also plays a positive role to minimize GHG emissions, particularly $\mathrm{CO}_{2}$ emissions through building smart cities, upgrading transportation systems, updating intelligent electrical grids systems, and industrial processes (Danish et al., 2018). Mainly ICT has two effects on $\mathrm{CO}_{2}$ emission: use effect and substation effect. The ICT usage effect comes from using digital PCs, internet servers, internet capability, fixed broadband, mobile telephone, LAN, and other related technologies to produce $\mathrm{CO}_{2}$ emission (Bastida et al., 2019), while the ICT substitution effect comes from using mechanizations to reduce $\mathrm{CO}_{2}$ emissions, for instance, using email in substitution of writing a letter, reading an e-book in substitution of a physical, printed book, using smart transportation systems for traffic, and other e-communication services (Asongu et al., 2018).

Today, global warming is not a prediction; it is an ongoing phenomenon. It is widely thought that economic activities produce different GHGs, especially $\mathrm{CO}_{2}$ emissions (Danish et al., 2019). Carbon dioxide $\left(\mathrm{CO}_{2}\right)$ emissions enter the atmosphere through the burning of carbon-containing fuels about soil attrition, solid waste, deforestation, animal breeding, and other biological materials (Belkhir and Elmeligi, 2018; Lin and Raza, 2019). According to the 6th report by the Intergovernmental Panel on Climate Change (IPCC), the average global temperature will be rise from $1.1^{\circ} \mathrm{C}$ to $6.4^{\circ} \mathrm{C}$ within the next 100 years (Bastida et al., 2019; Sarfraz et al., 2021a). Anthropogenic climate change is caused by multiple climate pollutants, with $\mathrm{CO}_{2}$ emission, $\mathrm{CH}_{4}$, and and $\mathrm{N}_{2} \mathrm{O}$ being the three largest individual contributors to global warming. Burning either fossil fuels or biomass is associated with all three of these gases $\left(\mathrm{CH}_{4}\right.$ and $\left.\mathrm{N}_{2} \mathrm{O}\right)$. It has been estimated that farm gate and including related land use emitted six billion tons of GHGs, about $13 \%$ of the total global emissions (Mahmood et al., 2019). Like other agrarian economies, agriculture is considered the backbone of Pakistan's economy, and agriculture contributes about $18.9 \%$ of Pakistan's gross domestic product (GDP) and employs $42.4 \%$ of the labor force. Pakistan is currently transitioning from an agriculture-led economy to an industry-led economy. This has resulted in an increase in energy consumption, which has adverse effects on climate change. According to Lin and Raza (2019), Pakistan contributes approximately $1 \%^{2}$ of the world's total $\mathrm{CO}_{2}$ emissions. A continuous increase in population size and country transitions from an agriculture-led economy to an industry-led economy increases the energy consumption in the country. It has been estimated that Pakistan is consuming more than $98 \%$ of nonrenewable energy sources that play a decisive role to pollute the environment in the country (Danish et al., 2017; Danish and Baloch, 2018).

Thus, given the background, it is important to assess the impact of ICT, economic growth, and globalization on $\mathrm{CO}_{2}$ emissions. While some of the pioneer studies (Anwar, 2016; Ishaque, 2017; Shahzad et al., 2017) empirically investigated the nexus between $\mathrm{CO}_{2}$ emissions and macroeconomic variables on the economy as a whole, there is a lack of research that focuses on how ICT, economic growth, and globalization can affect $\mathrm{CO}_{2}$ emissions. Moreover, the empirical evidence on how ICT contributes to environmental sustainability particularly in the perspective of Pakistan is scarce. Therefore, the current study will assess the impact of ICT on $\mathrm{CO}_{2}$ emission in general and more particularly in the perspective of Pakistan. Additionally, the existing literature paid much more attention to the advanced countries, whereas less-developed countries like Pakistan need more attention. Pakistan is the world's 6th most populous country, with unbalanced economic growth and development. As a result, the timely investigations of this study will assist Pakistan, as well as other developing countries in the region, in adopting policies that would maximize the benefits of ICT adoption to enhance their economies without damaging the environment.

The current study contributes to the existing research, as follows: first, this study assesses the impact of ICT and globalization on environmental quality in Pakistan. As per the authors' knowledge, a number of studies extensively assess the relationship between ICT and economic growth by using different methodologies and data set, but this particular area still needs to be researched by considering the relationship between ICT, globalization, and environmental quality in the context of Pakistan. Second, this study included the well-known Narayan and Popp (2010) test, which is better than the number of econometric techniques in the terms of accuracy, size, and power in identifying breaks. Lastly, we applied the most reliable timeseries data techniques for long-run estimation techniques, to adopt a structural break, known as a generalized linear model (GLM) and robust least square (ROBUSTLS). The econometric approach used in this study provides detailed insight for the policymakers in helping to answer the above questions and shaping sustainable environment policies for the country.

The rest of the paper is divided into the following section: Section 2 emphasizes the review of the literature and theoretical background. Section 3 focuses on corresponding data and research methodology. Section 4 discusses the empirical findings. Section 5 concludes the study.

\section{REVIEW OF LITERATURE AND THEORETICAL BACKGROUND}

\subsection{Study Background}

Several studies extensively discussed the nexus between economic growth and environmental degradation. Theoretically, the relation between economic growth and the environment was first established by Grossman et al. (1991), and later on, the concept of the environmental 
Kuznets curve (EKC) was extended by Panayotou (1993). According to the EKC hypothesis, an increase in income resulted in an increase in pollution in the early stages. However, upon reaching a threshold level, greater income leads to a reduction in pollution. However, the neoclassical economist Solow (1965) introduced the growth model. The growth model suggests that in the long run, economic growth is determined by exogenous factors like capital accumulation, population growth, and technological changes. These studies also identified that technological progress is an important factor of economic growth and development (Wan Lee and Brahmasrene, 2014; Salahuddin et al., 2016; Asongu et al., 2017). In the long run, the Solow Growth Model predicts that steady-state equilibrium growth is only possible through technological advancement. Here, the literature can be classified into two categories, part 1 emphasizes the role of ICT and $\mathrm{CO}_{2}$ emission, while part 2 emphasizes the role of economic growth and globalization on $\mathrm{CO}_{2}$ emissions in general (Abdullah et al., 2015).

\subsection{Information and Communication Technology and $\mathrm{CO}_{2}$ Emission}

The link between ICT and the environment has been examined by a number of studies. Recently, several empirical studies focused on analyzing how ICT adoption affects the environment. For instance, An Higón et al. (2017) initiated that there is a significant and positive correlation between ICT adoption and environmental degradation. Other micro-level survey data showed that using mobile phones consumes energy and that energy is generated in large powerhouses by large turban machines, which are mainly powered by burning oil, gas, or coal, which emit harmful gases that pollute the environment (Morello et al., 2016). Using the country-level data, Coroama et al. (2012) explored a positive correlation between ICT, environment, and economic growth, while the seminal paper by Hohne et al. (2011) analyzed the cross-sectional data and explored how mobile phones and the internet affect the environment. Mobile phones help people stay updated on the weather through reports and monitoring the environment, while the internet allows people to spread awareness and knowledge about the environment and take timely action to protect other people.

While other studies explored a positive association between the increasing usage of ICT and $\mathrm{CO}_{2}$ emissions per capita in developed countries (Sepehrdoust, 2018; Shah et al., 2021), the work of Zhang and Liu (2015) identified the direct and positive linkage between ICT and energy consumption by analyzing panel data for South Asian countries. In addition, Lu (2018) examined data on a sample of 38 countries over the periods 1990-2010 and identified the three-way relationship between ICT and the environment. Direct relationship-the ICT sector-is the major source of $\mathrm{CO}_{2}$ emissions due to its reliance on highenergy consumption. Indirect relationship-the indirect impacts of ICT on the environment- is greater than the direct impacts of the ICT sector on the environment. The uncertain relationship-the relationship of ICT with the environment-seems uncertain because of the rebound effects (Sarfraz et al., 2021b).

\subsection{Information and Communication Technology, Economic Growth, and Globalization}

The importance of ICT has been underscored in the growth literature over that the last couple of decades. The impact of ICT on economic growth has been documented comprehensively in the prior empirical and case studies. Moreover, the recent studies that used time series analysis (Cardona et al., 2013; Sepehrdoust, 2018) found that investment in ICT positively affects productivity growth in the United Kingdom. Similarly, Qureshi and Najjar (2017) explored the positive linkage between ICT and economic globalization in the long run. Additionally, the empirical results suggest that ICT increases productivity and reduces transaction costs (Iqbal et al., 2019b). Furthermore, other studies have found that ICT development had a significant relationship with globalization in advanced economies, due to greater access to technological advancement (Ollo-lópez and Aramendía-muneta, 2012; Niebel, 2014). Contrarily, the linkage between ICT development and globalization in developing countries is insignificant due to the lack of access to infrastructure and technological advancement in the lessdeveloped countries.

So far, theoretically speaking, the impact of personal technology such as wearable devices and mobile phones has increased the socioeconomic connectivity that leads to an increase in productivity growth in emerging economies ( $\mathrm{Lu}$, 2018). One study used country-level micro-data in India (Erumban and Das, 2016) and found a positive relationship between globalization and ICT (more specifically internet and mobile phone use) in the country. Moreover, the empirical results of the study show that mobile phone and internet usage increase productivity and decrease poverty in the country. A recent empirical study revealed that the long-term impact of ICT on Korean economic growth is significant and positive (Jung et al., 2013). Likewise, some macro studies have focused on the relationship between ICT, economic growth, and the environment. It was noted that "ICT for the green" is minimizing the negative impact of ICT on the environment and improving environmental sustainability at the same time (Morello et al., 2016; Salahuddin et al., 2016).

\section{DATA, MODEL CONSTRUCTION, AND ECONOMETRIC STRATEGY}

\subsection{Data Source}

The main purpose of the current study is to empirically analyze the impact of ICT, economic growth, and globalization on $\mathrm{CO}_{2}$ emission from the perspective of Pakistan, by applying generalized linear model (GLM) and robust least square (ROBUSTLS) techniques. The data of all variables are collected from the World Development Indicators (WDI) (World Bank database) for the period of 1990-2019 based on data availability. We discussed the motivation of the study in the Introduction. The dependent variable of the study is $\mathrm{CO}_{2}$ emission, which is measured in metric tons per capita, and 


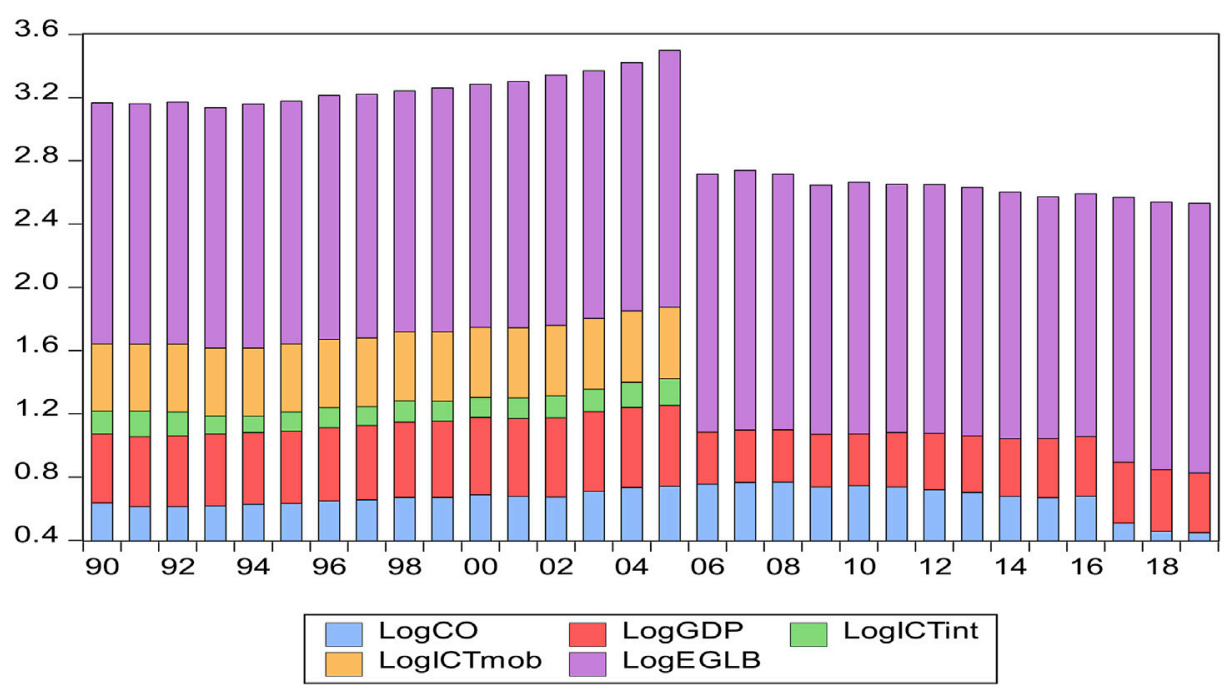

FIGURE 1 | The trend of $\mathrm{CO}_{2}$, gross domestic product (GDP), ICT $T_{\text {int }}, I \mathrm{IT}_{\text {mob }}$, and EGLB.

the data of $\mathrm{CO}_{2}$ emissions come from the World Bank, which is consistent with the literature (Hwang and Shin, 2017). ICT is the independent variable, which can be measured in two ways: monetary (includes ICT investment) and nonmonetary (includes mobile phones and internet broadband subscription) variables (Morello et al., 2016). Due to the nonavailability and limitations of the monetary variables, the current study will only focus on nonmonetary ICT variables. The data of nonmonetary variables (more specifically the number of internets and mobile users per 100 populations) are collected from the World Bank (Canarella and Miller, 2017), while the economic growth is measured as real GDP per capita (in constant 2010 USD) (Danish et al., 2019). Economic globalization is calculated through the KOF index of globalization (Hassan et al., 2019). To reduce the variable omission bias concerns, we use economic globalization as a control variable. Further trends of the investigated variables are represented in Figure 1.

\subsection{Model Specification}

Previous relevant literature and methodology, such as the research by Hassan et al. (2019), are adopted for benchmark regression equation showing how ICT, economic growth, and economic globalization influence the $\mathrm{CO}_{2}$ emission, expressed as

$$
\begin{aligned}
\log C O_{2 i t}= & a_{0}+a_{1}\left(\log I C T_{i t}\right)+a_{2}\left(\log G D P_{i t}\right) \\
& +a_{3}\left(\operatorname{LogGlob}_{i t}\right)+\omega
\end{aligned}
$$

In Eq. (1), $\log \mathrm{CO}_{2}$ is the carbon dioxide $\left(\mathrm{CO}_{2}\right)$ emissions; $\operatorname{logICT}$ is the ICT (the data of nonmonetary variables, such as the number of internets and mobile users); logGDP is the real GDP per capita; and LogGlob is economic globalization. Moreover, here in the equation, $\omega, i$, and $t$ are residual error terms and time, respectively.

\subsection{Econometric Strategy \\ 3.3.1 Unit Root Test With Two Structural Breaks (Narayan and Popp)}

Several different unit tests have emerged to check the stationarity of data. Here, a series of unit root tests are applied to check the stationarity of the investigated variables. It is important to confirm the stationarity level in the time series data analysis for advanced econometrics techniques used in the analysis. For checking the stationarity among investigated variables, the current study applied the augmented Dickey-Fuller (ADF), Phillips-Perron, and Dickey-FullerGeneralized Least Squares (DF-GLS) unit root tests. The procedure and unit root test analysis have been already discussed in the existing literature in detail. Moreover, here, the new unit root test is applied with two structural breaks developed by Narayan and Popp. ${ }^{14}$ Additionally, the simulation called Monte Carlo was also suggested by Narayan and Popp. The advantages of the two structural break unit root tests are their well-stabilized power and accuracy in differentiating actual break dates. Successively, this approach has been used to establish the integration order for each series. To test the integration, the authors developed two types of models: Model 1 examines structural breaks and intercepts only, while Model 2 incorporates trend breaks in both slope and intercept.

\subsubsection{Bayer-Hanck Cointegration}

In the existing literature, several cointegration methods are applied (Engle and Granger, 1987; Johansen, 1991; Banerjee et al., 1998). However, many of the techniques presented in the literature are out of date, which could lead to vague empirical results. To overcome this issue, Bayer and Hanck (2013) proposed a new combined cointegration method to address this issue and further strengthen the cointegration analysis. 


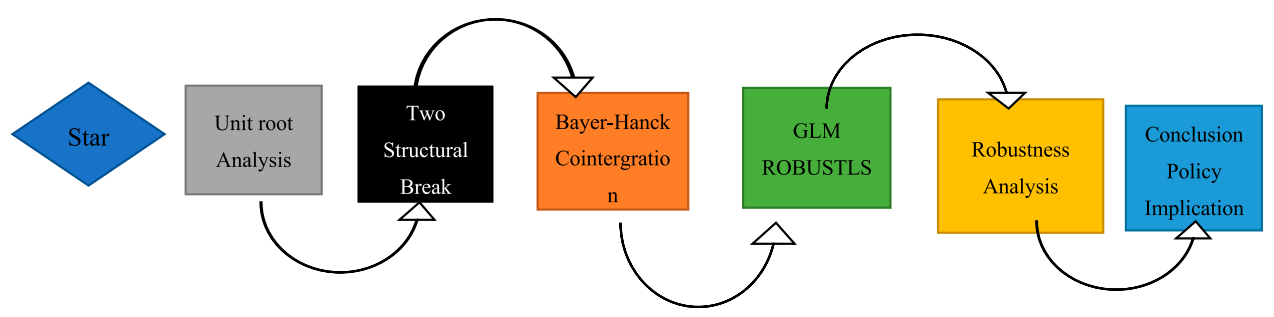

FIGURE 2 | Procedure of long-run estimation.

This method is quite helpful to improve the cointegration combination analysis from earlier cointegration approaches and uses Fisher's F-statistics that are in line with empirical results. The order for this methodology should be I(I), whereas the value for the F-statistics if greater than the critical value should reject the null hypothesis and vice versa. Their cointegration can be shown as follows:

$$
\begin{gathered}
E G J O H=2[\log (P E G)+\log (P J O H)] \\
E G J O H B O B D M=2 \log [(P E G)+(P B O)+(P B D M)]
\end{gathered}
$$

The ultimate purpose of applying Fisher's statistics is to find out whether the variables are cointegrated. Moreover, to get authentic results, the study also applied the bound testing technique.

\subsubsection{Long-Run Estimation Technique}

The GLM (Dutter, 1977) and ROBUSTLS (Baum et al., 2003) approaches were applied to estimate long run. The GLM helps in non-normal stochastic and nonlinear systematic components of linear regressions. Furthermore, it helps in the assumption in the association of distribution of the model with robust the motivational development of the estimators as well as the covariance of the quasi-maximum likelihood (QML), while ROBUSTLS resolves the issue of the outliers' independent and explanatory variables to make sure of unbiased results (Rousseeuw and Yohai, 1984). These advanced econometric models have significant contributions to the literature. The empirical steps are shown in Figure 2.

\section{EMPIRICAL RESULTS AND DISCUSSION}

\subsection{Unit Root Tests}

The results will be considered significant only when the variables used in the regressions are either stationary or integrated. In the time series analysis, before applying Auto-Regressive Distributed Lag (ARDL), for long long-run estimation, the variable must be tested for stationarity; the results are reported in Table 1. To ensure the order of integration, three commonly used tests (Phillips-Perron, degree of freedom-flexible least square (DG-FLS), and ADF) statistics are employed. The main purpose of this study is to examine the impact of ICT, economic growth, and economic globalization on $\mathrm{CO}_{2}$ emissions in the context of Pakistan for the period of 1990-2019.
Thus, there is a chance that the series may be nonstationary, and the results produced are not accurate economically and statistically (Wan Lee and Brahmasrene, 2014). Overall, the results of the unit root test in Table 1 indicate that there is no evidence for the existence of unit root for any of the mentioned variables. In this regard, this study concludes that ICT, $\mathrm{CO}_{2}$, economic growth (GDP), and globalization (Glob) are integrated at first-order difference I(1) or I(0). So the estimations conducted later are meaningful and would not suffer from spurious regression, and we claim that ARDL can be pursued.

\subsection{Two-Structural-Break Unit Root Test}

The results of the ADF and Phillips-Perron (PP) series unit root test one demonstrate that all the variables under investigation are integrated at I(1), which is ambiguous and also unable to identify a break year point. To tackle the issue of structural breaks, we used the Narayan and Popp structural break methodology. This method allows structural breaks, which reveals the level and trend of the series, which is not suggested by any other methodology. This gives very efficient two structural breaks as shown in Table 2. The unit root results indicate that none of the variables is nonstationary at $\mathrm{I}(0)$ and confirm that our two LONR and LOGTR are stationary at I(1). Therefore, we can move to the next step for checking the long-term relationship between variables by using ARDL bond cointegration.

\subsection{Bayer and Hanck Cointegration}

In the Bayer and Hanck cointegration test, calculated statistics are compared with critical values. We reject the null hypothesis if the calculated F-statistics value is greater than the critical, and vice versa. The results of the combined integration analysis are shown in Table 3. By considering the calculated statistics, the finding of the study shows that there is a cointegration relationship between study variables for Pakistan. Hence, we need to apply the long-run estimation technique GLM and ROBUST.

\subsection{Long-Run and Short-Run Estimations}

Here, we assess the long-run and short-run coefficients of the study. For this purpose, we applied the GLM, ROBUSLS, and vector error correction model (VECM) econometric techniques. Table 4 comprises the estimated long-run and short-run results of the study. The $\mathrm{CO}_{2}$ emission is the dependent variable in the model, while the ICT (ICT-internet and ICT-mobile), economic growth, and economic globalization are independent variables in the model. All variables are transformed into logarithmic form in Eq. 1 . 
TABLE 1 | Unit root test.

\begin{tabular}{|c|c|c|c|c|c|c|}
\hline \multirow[t]{2}{*}{ Variables } & \multicolumn{2}{|c|}{ ADF unit root test } & \multicolumn{2}{|c|}{ Phillips-Perron unit root test } & \multicolumn{2}{|c|}{ DF-GLS unit root test } \\
\hline & Level & 1st def & Level & 1st def & Level & 1st def \\
\hline $\mathrm{LOGCO}_{2}$ & -1.3245 & $-4.5756^{\star}$ & -1.3148 & $-4.6111^{*}$ & -0.6895 & -4.1648 \\
\hline LogGDP & 0.8507 & $-3.2377^{*}$ & -0.3526 & $-3.0188^{*}$ & 0.0446 & $-3.2627^{\prime}$ \\
\hline LogGLB & -3.0790 & $-2.0582^{*}$ & -2.8676 & $-1.9420^{*}$ & -1.1201 & -2.2045 \\
\hline LoglCT $_{\text {mob }}$ & -3.1664 & $-3.8653^{*}$ & -3.1664 & $-3.8477^{\star}$ & -1.6136 & -3.8632 \\
\hline LoglCT $_{\text {int }}$ & 0.5371 & $-2.7790^{*}$ & 0.6715 & $-2.9147^{*}$ & -0.6549 & -2.7586 \\
\hline
\end{tabular}

Note. ADF, augmented Dickey-Fuller,

* $1 \%$ level of significance.

TABLE 2 | Results of structural break unit root tests.

\begin{tabular}{|c|c|c|c|c|c|c|}
\hline \multirow[t]{2}{*}{ Variables } & \multicolumn{5}{|c|}{ Model M1 } & \multirow{2}{*}{ 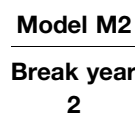 } \\
\hline & t-Statistics & $\begin{array}{c}\text { Break year } \\
1\end{array}$ & $\begin{array}{c}\text { Break year } \\
2\end{array}$ & t-Statistics & $\begin{array}{c}\text { Break year } \\
1\end{array}$ & \\
\hline $\mathrm{LogCO}_{2}$ & -1.1184 & 1993 & 2004 & $-7.0042^{\star}$ & 1996 & 2008 \\
\hline LogGDP & -0.4075 & 1996 & 2001 & -2.6836 & 1998 & 2003 \\
\hline LogGLB & -0.3185 & 2009 & 2013 & $-6.0273^{*}$ & 2000 & 2007 \\
\hline $\log \mathrm{CT}_{\text {mob }}$ & -1.049 & 1990 & 2001 & -3.6988 & 1997 & 2003 \\
\hline LoglCT $_{\text {int }}$ & -2.4534 & 2006 & 2012 & -4.8608 & 1983 & 1991 \\
\hline \multirow[t]{5}{*}{ LoglTrade } & -1.4891 & 2005 & 2014 & -3.6192 & 1885 & 1999 \\
\hline & Critical value $\mathrm{M} 1$ & & value $\mathrm{M} 2 \mathrm{0 \%}$ & & & \\
\hline & $10 \%$ & -4.101 & & & & \\
\hline & $5 \%$ & -4.321 & & $5 \%$ & 5.521 & \\
\hline & $1 \%$ & -5.251 & & $1 \%$ & 5.921 & \\
\hline
\end{tabular}

The study's main finding is presented in Table 4. All the coefficients have estimated signs; all the series are significant at a $0.05 \%$ level of significance. Focusing on the long run, the results indicate that GDP (real GDP), ICT (particularly ICTinternet and ICT-mobile subscription), and economic globalization have a significant link with $\mathrm{CO}_{2}$ emission. Moreover, in the long run, the coefficient of economic growth (real GDP) has a positive and significant effect on environmental degradation, which confirms that economic growth (real GDP) accelerates the rate of $\mathrm{CO}_{2}$ emission. A $1 \%$ increase in economic growth (real GDP) leads to an increase $[1.5799 \%$ and $0.0324 \%]$ in environmental degradation. The results indicate that, in the early stages of economic growth, the level of pollution increases to a certain level, and after a certain level, the level of pollution starts decreasing. The results of this study are similar to those of the recent work of Dehghan and Shahnazi (2019). The work of Danish et al. (2019) also emphasizes that the increase in income is the main source of $\mathrm{CO}_{2}$ emission, based on the notion that an increase in production equals to increase in pollution.

In Table 4, the coefficient of ICT usage (particularly ICTinternet and ICT-mobile subscription) has a negative but significant effect on the pollution equation, which confirms that the usage of ICT (particularly ICT-internet and ICTmobile subscription) does not contribute positively to $\mathrm{CO}_{2}$ emission. The results show that the effective use of ICT (particularly ICT-internet and ICT-mobile subscription) plays a positive role to reduce $\mathrm{CO}_{2}$ emission. Like other developing countries recently, ICT is one of the fastest-growing sectors in Pakistan. Approximately 70 million citizens have access to ICT (internet and mobile subscription) (Shaikh and Khoja, 2016). Most of the developing countries including Pakistan has started the usage of smart applications such as e-commerce, intelligent transportation system, e-communication, e-health, e-governance, e-banking, virtual education, smart building, manufacturing,

TABLE 3 | Results of Bayer-Hanck.

\begin{tabular}{|c|c|c|c|}
\hline $\begin{array}{l}\mathrm{CO}_{2}=\mathrm{GDP}, \mathrm{EGLOB}, \mathrm{ICT} \mathrm{T}_{\text {int }}, \\
\mathrm{ICT}_{\text {mob }}\end{array}$ & EG-JOH & EG-JOH-BO-BDM & Decision \\
\hline & 18.12451 & 28.92145 & Cointegra \\
\hline
\end{tabular}

Note. Decision criteria for EG-JOH and EG-JOH-BO-BDM are 10.719 and 20.691, respectively. 
TABLE 4 | Long-run and short-run results.

\begin{tabular}{|c|c|c|c|c|c|c|c|}
\hline \multirow{2}{*}{$\frac{\text { Dependent }=\mathrm{CO}_{2}}{\text { Variable }}$} & \multicolumn{4}{|c|}{ GLM } & \multicolumn{3}{|c|}{ ROBUSTLS } \\
\hline & Coefficient & $Z$ test & Prob & Variable & Coefficient & $\mathbf{Z}$ test & Prob \\
\hline LogGDP & $1.5799^{\star}$ & 5.6513 & 0.000 & LogGDP & $0.0324^{\star \star}$ & 0.0912 & 0.016 \\
\hline $\log I C T_{\text {int }}$ & $-0.0078^{\star \star}$ & -1.0409 & 0.014 & LoglCT $_{\text {int }}$ & $-0.0019^{\star \star}$ & 2.3866 & 0.025 \\
\hline LoglCT $_{m o b}$ & $-0.0088^{\star}$ & 1.3559 & 0.006 & $\operatorname{LoglCT}_{\text {mob }}$ & $-0.0053^{\star}$ & -9.5355 & 0.000 \\
\hline LogEGLOB & $0.0734^{*}$ & 4.1064 & 0.000 & LogEGLOB & $0.0892^{*}$ & 5.1275 & 0.000 \\
\hline \multicolumn{8}{|l|}{ Diagnostic test } \\
\hline R-squared & 0.985680 & & & & & & \\
\hline F-statistics & 157.3297 & & & & & & \\
\hline Durbin-Watson stat & 2.334682 & & & & & & \\
\hline \multicolumn{8}{|l|}{ Sensitivity analysis } \\
\hline Ramsey reset & 0.300352 [0.5917] & & & & & & \\
\hline$\chi^{2}-L M$ & 1.065439 [0.3709] & & & & & & \\
\hline$x^{2}-\mathrm{ARCH}$ & $0.015681[0.9015]$ & & & & & & \\
\hline
\end{tabular}

Note. GLM, generalized linear model; ROBUSTLS, robust least square; LM, Lagrange multiplier; ARCH, autoregressive conditional heteroscedasticity.

* The level of rejection at the $10 \%$ level of significance.

** The level of rejection at the $5 \%$ level of significance.

${ }^{* * *}$ The level of rejection at the $1 \%$ level of significance.

\begin{tabular}{|c|c|c|c|c|c|c|}
\hline & $\mathrm{CO}_{2}$ & GDP & $\mathrm{ICT}_{\text {int }}$ & Glob & $\mathrm{ICT}_{\mathrm{mob}}$ & $\operatorname{Ecm}(-1)$ \\
\hline $\mathrm{CO}_{2}$ & - & 1.95602 (0.1789) & 1.09479 (0.3093) & $1.19878(0.2880)$ & 0.88756 (0.3586) & -0.0721 [0.0358] \\
\hline GDP & 3.96635 (0.0618) & - & $0.54614(0.4694)$ & $0.00115(0.9732)$ & $0.00694(0.9345)$ & $0.004732[0.9345]$ \\
\hline $\mathrm{ICT}_{\text {int }}$ & 1.88807 (0.1863) & $0.02341(0.8801)$ & - & $0.03129(0.8616)$ & $2.464538(0.1339)$ & $0.098144[0.1339]$ \\
\hline Glob & $1.30883(0.2676)$ & $0.17572(0.6800)$ & $0.72722(0.4050)$ & - & $4.764055(0.0426)$ & $-0.35430[0.0426]$ \\
\hline$I C T_{\text {mob }}$ & 0.971866 (0.3373) & 0.011469 (0.9159) & $0.481648(0.4965)$ & $0.168506(0.6863)$ & - & $-0.084000[0.0065]$ \\
\hline
\end{tabular}

Note. VECM, vector error correction model.

${ }^{*},{ }^{* *}$, and ${ }^{* *}$ indicate the level of significance at $1 \%, 5 \%$, and $10 \%$.

GPS, travel services, virtual meetings, and logistics, mainly reducing $\mathrm{CO}_{2}$ emissions ( $\mathrm{Lu}, 2018$ ). Moreover, the coefficient of economic globalization has a positive and significant effect on the pollution equation, which confirms that globalization accelerates $\mathrm{CO}_{2}$ emissions. It shows that, in the early stage of development for any country, investing vast sums of money on infrastructure (including ICT), roads and communications, transportation, and other mega projects causes the environmental degradation of that country.

In Table 4, the value of R-squared is $0.985,680$, which shows a $98 \%$ deviation in the model. The F-statistics shows that the joint significance is $1 \%$, which is confirmed when the independent variables are included. The value of the Durbin-Watson statistics is 2.334, which indicates that no autocorrelation exists. This number is not equal to the Durbin-Watson standard value, but it is sufficient to reveal any autocorrelation in the model.

\subsection{Granger Causality Analysis}

This study examines the causal relationship among variables in the short run and long run by using the Granger causality approach to detect the direction. Table $\mathbf{5}$ summarizes the findings. These results can be discussed as follows: for internet usage, no causal relationship has been detected among the mentioned variables. However, in the short run for mobile usage, bidirectional causal relationships were found between the GDP and $\mathrm{CO}_{2}$ emission, suggestion feedback hypothesis. Furthermore, there is no causal relationship found between mobile usage and $\mathrm{CO}_{2}$ emission. In addition, in Figure 3, we construct various theoretical graphs for quantiles on quantiles. All chosen variables are measured by quantiles on normal distribution quantities. The study reveals that the variables under investigation are normally distributed, and data points fall in a roughly straight path.

\subsection{Structural Stability Test}

Several diagnostic tests are also carried out to make sure the reliability of the model, which includes the Ramsey reset test for normality, autoregressive conditional heteroscedasticity (ARCH) for heteroscedasticity, and Lagrange multiplier (LM) for serial correlation. The results of mentioned tests are stated in Table 4; the Ramsey reset test, $\mathrm{ARCH}$, and LM test suggest that the model is reliable and independent of the issues of heteroscedasticity and autocorrelation. 


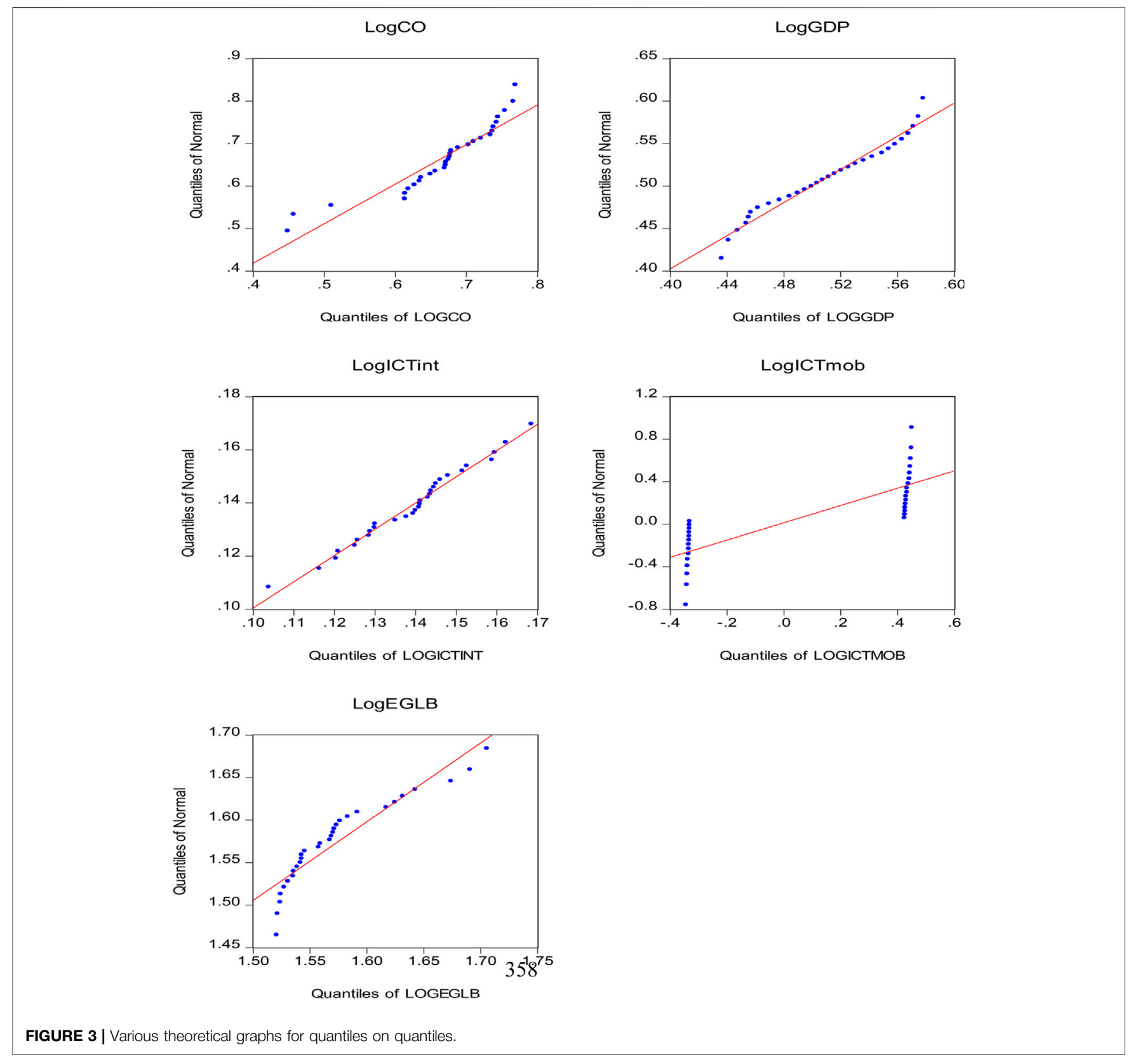

\section{CONCLUSION}

The main goal of the current study was to investigate the impact of ICT, economic growth, and economic globalization on $\mathrm{CO}_{2}$ emissions in the context of Pakistan. For empirical estimations, we employed the GLM and ROBUSTLS econometric techniques for the period 1990-2019. The key findings of this study revealed that the intensity of ICT usage (more specifically internet and mobile subscription) has a negative but statistically significant effect on the pollution equation, which confirms that the usage of ICTs does not contribute positively to $\mathrm{CO}_{2}$ emission in the long run. The empirical results of the study also revealed that economic growth (real GDP) had a positive and statistically significant effect on $\mathrm{CO}_{2}$ emission, which confirms that economic growth (GDP) accelerates the rate of $\mathrm{CO}_{2}$ emission. Furthermore, the coefficient of globalization has a positive and significant effect on the pollution equation, which confirms that globalization accelerates $\mathrm{CO}_{2}$ emissions in the long run, whereas in the short run, the empirical results indicate that economic growth (real GDP) has a positive but insignificant association with $\mathrm{CO}_{2}$ emission, while ICT (internet and mobile subscription) has a negative but significant association with $\mathrm{CO}_{2}$ emissions.

To reduce $\mathrm{CO}_{2}$ emissions, the current study offers several policy recommendations, particularly for Pakistan to reduce $\mathrm{CO}_{2}$ emissions. Like the few other service sectors, the ICT sector has 
the potential to play an important role in reducing $\mathrm{CO}_{2}$ emissions in developing countries, including Pakistan. ICT has sophisticated and user-friendly applications that, in turn, widen the population segment and result in reducing $\mathrm{CO}_{2}$ emissions in the country. The following recommendations are suggested for the policymakers in Pakistan: first, compile ICT policies for up-to-date applications in the country to reduce $\mathrm{CO}_{2}$ emissions. Second, strengthen the infrastructure and connectivity (internet and mobile subscriptions) to increase sustainable development in the country. Lastly, promote e-culture (digitalization) in the country to reduce $\mathrm{CO}_{2}$ emissions and increase sustainable development.

In short, the global economic structure has changed drastically because of advancements in ICT. In addition, an increase in ICT usage has a significant impact on long-term $\mathrm{CO}_{2}$ emissions and economic growth. As a result, development policies should be designed to increase ICT penetration rates, which further ensured long-term sustainable economic growth and minimize $\mathrm{CO}_{2}$

\section{REFERENCES}

Abdullah, M. I., Sarfraz, M., Sarfraz, M., Qun, W., and Javaid, N. (2018). Drivers of green Supply Chain Management. LogForum 14, 437-447. doi:10.17270/ J.LOG.2018.297

Añón Higón, D., Gholami, R., and Shirazi, F. (2017). ICT and Environmental Sustainability: A Global Perspective. Telematics Inform. 34, 85-95. doi:10.1016/ j.tele.2017.01.001

Anwar, J. (2016). Analysis of Energy Security, Environmental Emission and Fuel Import Costs under Energy Import Reduction Targets: A Case of Pakistan. Renew. Sustain. Energ. Rev. 65, 1065-1078. doi:10.1016/ j.rser.2016.07.037

Asongu, S. A., Le Roux, S., and Biekpe, N. (2017). Environmental Degradation, ICT and Inclusive Development in Sub-saharan Africa. Energy Policy 111, 353-361. doi:10.1016/j.enpol.2017.09.049

Asongu, S. A., Le Roux, S., and Biekpe, N. (2018). Enhancing ICT for Environmental Sustainability in Sub-saharan Africa. Technol. Forecast. Soc. Change 127, 209-216. doi:10.1016/j.techfore.2017.09.022

Banerjee, A., Dolado, J., and Mestre, R. (1998). Error-correction Mechanism Tests for Cointegration in a Single-Equation Framework. J. Time Ser. Anal. 19, 267-283. doi:10.1111/1467-9892.00091

Bastida, L., Cohen, J. J., Kollmann, A., Moya, A., and Reichl, J. (2019). Exploring the Role of ICT on Household Behavioural Energy Efficiency to Mitigate Global Warming. Renew. Sustain. Energ. Rev. 103, 455-462. doi:10.1016/ j.rser.2019.01.004

Baum, C. F., Schaffer, M. E., and Stillman, S. (2003). Instrumental Variables and GMM: Estimation and Testing. Stata J. 3, 1-31. doi:10.1177/ 1536867X0300300101

Bayer, C., and Hanck, C. (2013). Combining Non-cointegration Tests. J. Time Ser. Anal. 34, 83-95. doi:10.1111/j.1467-9892.2012.00814.x

Belkhir, L., and Elmeligi, A. (2018). Assessing ICT Global Emissions Footprint: Trends to 2040 \& Recommendations. J. Clean. Prod. 177, 448-463. doi:10.1016/ j.jclepro.2017.12.239

Canarella, G., and Miller, S. M. (2018). The Determinants of Growth in the U.S. Information and Communication Technology (ICT) Industry: A Firm-Level Analysis. Econ. Model. 70, 259-271. doi:10.1016/j.econmod.2017.11.011

Cardona, M., Kretschmer, T., and Strobel, T. (2013). ICT and Productivity: Conclusions from the Empirical Literature. Inf. Econ. Pol. 25, 109-125. doi:10.1016/j.infoecopol.2012.12.002

Coroama, V. C., Hilty, L. M., and Birtel, M. (2012). Effects of Internet-Based Multiple-Site Conferences on Greenhouse Gas Emissions. Telematics Inform. 29, 362-374. doi:10.1016/j.tele.2011.11.006

Danish and Baloch, M. A. (2018). Dynamic Linkages between Road Transport Energy Consumption, Economic Growth, and Environmental Quality: emissions. Due to the nonavailability and limitations of the monetary variables, the current study only focuses on nonmonetary ICT variables. In the future, similar studies can be carried out for other countries by including nonmonetary variable data.

\section{DATA AVAILABILITY STATEMENT}

The raw data supporting the conclusion of this article will be made available by the authors, without undue reservation.

\section{AUTHOR CONTRIBUTIONS}

KI: writing of the initial draft. SH: writing-analysis and methodology. YW: writing literature review. MHS: editing. MS: reviewed the manuscript KK: proofreading.

Evidence from Pakistan. Environ. Sci. Pollut. Res. 25, 7541-7552. doi:10.1007/s11356-017-1072-1

Danish, Zhang, B., Wang, B., and Wang, Z. (2017). Role of Renewable Energy and Non-renewable Energy Consumption on EKC: Evidence from Pakistan. J. Clean. Prod. 156, 855-864. doi:10.1016/j.jclepro.2017.03.203

Danish, Wang, B., and Wang, Z. (2018). Imported Technology and CO2 Emission in China: Collecting Evidence through Bound Testing and VECM Approach. Renew. Sustain. Energ. Rev. 82, 4204-4214. doi:10.1016/j.rser.2017.11.002

Danish, Hassan, S. T., Baloch, M. A., Mahmood, N., and Zhang, J. (2019). Linking Economic Growth and Ecological Footprint through Human Capital and Biocapacity. Sustain. Cities Soc. 47, 101516. doi:10.1016/j.scs.2019.101516

Dehghan, Z., and Shahnazi, R. (2019). Energy Consumption, Carbon Dioxide Emissions, Information and Communications Technology, and Gross Domestic Product in Iranian Economic Sectors: A Panel Causality Analysis. Energy 169, 1064-1078. doi:10.1016/j.energy.2018.11.062

Dutter, R. (1977). Algorithms for the Huber Estimator in Multiple Regression. Computing 18, 167-176. doi:10.1007/BF02243626

Engle, R. F., and Granger, C. W. J. (1987). Co-Integration and Error Correction: Representation, Estimation, and Testing. Econometrica 55, 251. doi:10.2307/ 1913236

Erumban, A. A., and Das, D. K. (2016). Information and Communication Technology and Economic Growth in India. Telecomm. Policy 40, 412-431. doi:10.1016/j.telpol.2015.08.006

Grossman, G. M., Krueger, A. B., Brown, D., Evans, G., and Schoepfle, G. (1991). Massachusetts Avenue Jeff Mackie-Mason provided Helpful Comments and Gene. NBER Working Papers Series 1050.

Hassan, S. T., Xia, E., Huang, J., Khan, N. H., and Iqbal, K. (2019). Natural Resources, Globalization, and Economic Growth : Evidence from Pakistan. Environ. Sci. Pollut. Res. Int. 26, 15527. doi:10.1007/s11356-019-04890-z

Höhne, N., Blum, H., Fuglestvedt, J., Skeie, R. B., Kurosawa, A., Hu, G., et al. (2011). Contributions of Individual Countries' Emissions to Climate Change and Their Uncertainty. Climatic Change 106, 359-391. doi:10.1007/s10584-010-9930-6

Hwang, W.-S., and Shin, J. (2017). ICT-specific Technological Change and Economic Growth in Korea. Telecomm. Policy 41, 282-294. doi:10.1016/ j.telpol.2016.12.006

Iqbal, K., Hassan, S. T., Peng, H., and Khurshaid (2019a). Analyzing the Role of Information and Telecommunication Technology in Human Development: Panel Data Analysis. Environ. Sci. Pollut. Res. 26, 15153-15161. doi:10.1007/ s11356-019-04918-4

Iqbal, K., Peng, H., Hafeez, M., and Khurshaid (2019b). Analyzing the Effect of ICT on Migration and Economic Growth in Belt and Road (BRI) Countries. Int. Migration Integration 21, 307-318. doi:10.1007/s12134-019-00739-z

Ishaque, H. (2017). Quantifying the Potential Impact of Pakistan's GHG Mitigation Policies for Coal-Fired Power Plants. Energ. Proced. 142, 2809-2815. doi:10.1016/j.egypro.2017.12.426 
Johansen, S. (1991). Estimation and Hypothesis Testing of Cointegration Vectors in Gaussian Vector Autoregressive Models. Econometrica 59, 1551. doi:10.2307/ 2938278

Jung, H.-J., Na, K.-Y., and Yoon, C.-H. (2013). The Role of ICT in Korea's Economic Growth: Productivity Changes across Industries since the 1990s. Telecomm. Policy 37, 292-310. doi:10.1016/j.telpol.2012.06.006

Lin, B., and Raza, M. Y. (2019). Analysis of Energy Related CO2 Emissions in Pakistan. J. Clean. Prod. 219, 981-993. doi:10.1016/j.jclepro.2019.02.112

Lu, W.-C. (2018). The Impacts of Information and Communication Technology, Energy Consumption, Financial Development, and Economic Growth on Carbon Dioxide Emissions in 12 Asian Countries. Mitig Adapt Strateg. Glob. Change 23, 1351-1365. doi:10.1007/s11027-018-9787-y

Mahmood, N., Wang, Z., Yasminf, N., Manzoor, W., and Atteeq-ur-Rahman (2019). How to bend Down the Environmental Kuznets Curve the Significance of Biomass Energy. Environ. Sci. Pollut. Res. 26. doi:10.1007/s11356-01905442-1

Morello, E., Toffolo, S., and Magra, G. (2016). Impact Analysis of Ecodriving Behaviour Using Suitable Simulation Platform (ICT-EMISSIONS Project). Transport. Res. Proced. 14, 3119-3128. doi:10.1016/j.trpro.2016.05.252

Narayan, P. K., and Popp, S. (2010). A New Unit Root Test with Two Structural Breaks in Level and Slope at Unknown Time. J. Appl. Stat. 37, 1425-1438. doi:10.1080/02664760903039883

Niebel, T. (2014). ICT and Economic Growth - Comparing Developing, Emerging and Developed Countries (No. 14- 117 ICT). Mennheim.

Ollo-López, A., and Aramendía-Muneta, M. E. (2012). ICT Impact on Competitiveness, Innovation and Environment. Telematics Inform. 29, 204-210. doi:10.1016/j.tele.2011.08.002

Panayotou, T. (1993). Empirical tests and policy analysis of environmental degradation at different stages of economic development, ILO Working Papers, International Labour Organization. Available at: https://EconPapers.repec.org/RePEc:ilo:ilowps: 992927783402676.

Park, Y., Meng, F., and Baloch, M. A. (2018). The Effect of ICT, Financial Development, Growth, and Trade Openness on CO2 Emissions: an Empirical Analysis. Environ. Sci. Pollut. Res. 25, 30708-30719. doi:10.1007/ s11356-018-3108-6

Qureshi, S., and Najjar, L. (2017). Information and Communications Technology Use and Income Growth: Evidence of the Multiplier Effect in Very Small Island States. Inf. Techn. Dev. 23, 212-234. doi:10.1080/02681102.2016.1173634

Rousseeuw, P., and Yohai, V. (1984). Robust Regression by Means of S-Estimators," in Robust and Nonlinear Time Series Analysis. Lecture Notes in Statistics. Editor J. Franke, W. Härdle, and D. Martin (New York, NY: Springer), 26. doi:10.1007/978-1-4615-7821-5_15

Salahuddin, M., Alam, K., and Ozturk, I. (2016). The Effects of Internet Usage and Economic Growth on CO2 Emissions in OECD Countries: A Panel Investigation. Renew. Sustain. Energ. Rev. 62, 1226-1235. doi:10.1016/j.rser.2016.04.018

Sarfraz, M., Ivascu, L., Belu, R., and Artene, A. (2021a). Accentuating the Interconnection between Business Sustainability and Organizational Performance in the Context of the Circular Economy: The Moderating Role of Organizational Competitiveness. Bus Strat .Env. 30, 2108-2118. doi:10.1002/bse.2735

Sarfraz, M., Mohsin, M., Naseem, S., and Kumar, A. (2021b). Modeling the Relationship between Carbon Emissions and Environmental Sustainability during COVID-19: a New Evidence from Asymmetric ARDL Cointegration Approach. Environ. Dev. Sustain. 23, 16208-16226. doi:10.1007/s10668-02101324-0

Sepehrdoust, H. (2018). Impact of Information and Communication Technology and Financial Development on Economic Growth of OPEC Developing Economies. Kasetsart J. Soc. Sci., 6-11. doi:10.1016/j.kjss.2018.01.008

Shah, S. G. M., Sarfraz, M., and Ivascu, L. (2021). Assessing the Interrelationship Corporate Environmental Responsibility, Innovative Strategies, Cognitive and Hierarchical CEO : A Stakeholder Theory Perspective. Corp. Soc. Responsib. Environ. Manag. 28, 457-473. doi:10.1002/csr.2061

Shahzad, S. J. H., Kumar, R. R., Zakaria, M., and Hurr, M. (2017). Carbon Emission, Energy Consumption, Trade Openness and Financial Development in Pakistan: A Revisit. Renew. Sustain. Energ. Rev. 70, 185-192. doi:10.1016/ j.rser.2016.11.042

Shaikh, Z. A., and Khoja, S. (2016). Role of ICT in Shaping the Future of Pakistani Higher Education System. J Turkish Online Technol. Educ. 10, 149-161. doi:10.7763/IJCTE.2013.V5.720

Solow, R. M. (1965). Human Capital. Gary S. Becker. J. Polit. Economy 73, 552-553. doi:10.1086/259081

Wan Lee, J., and Brahmasrene, T. (2014). ICT, CO2Emissions and Economic Growth: Evidence from a Panel of ASEAN. Glob. Econ. Rev. 43, 93-109. doi:10.1080/1226508X.2014.917803

Zhang, C., and Liu, C. (2015). The Impact of ICT Industry on CO2 Emissions: A Regional Analysis in China. Renew. Sustain. Energ. Rev. 44, 12-19. doi:10.1016/ j.rser.2014.12.011

Conflict of Interest: The authors declare that the research was conducted in the absence of any commercial or financial relationships that could be construed as a potential conflict of interest.

Publisher's Note: All claims expressed in this article are solely those of the authors and do not necessarily represent those of their affiliated organizations, or those of the publisher, the editors, and the reviewers. Any product that may be evaluated in this article, or claim that may be made by its manufacturer, is not guaranteed or endorsed by the publisher.

Copyright (C) 2022 Iqbal, Hassan, Wang, Shah, Syed and Khurshaid. This is an openaccess article distributed under the terms of the Creative Commons Attribution License (CC BY). The use, distribution or reproduction in other forums is permitted, provided the original author(s) and the copyright owner(s) are credited and that the original publication in this journal is cited, in accordance with accepted academic practice. No use, distribution or reproduction is permitted which does not comply with these terms. 